\title{
Measurement of Neutron Flux and Gamma Dose Rate Distribution Inside a Water Phantom for Boron Neutron Capture Therapy Study at Dalat Research Reactor \\ (Pengukuran Neutron Fluks dan Pengagihan Kadar Dos Gama dalam Fantom Air untuk Kajian Terapi Boron Neutron Tertawan di Reaktor Penyelidikan Dalat)
}

Trinh Thi Tu AnH*, Pham Dang Quyet, Mai Nguyen Trong Nhan \& Pham Ngoc Son

\author{
ABSTRACT
}

Exposure dose rate to the tumor and surrounding cells during neutron beam irradiation in Boron Neutron Capture Therapy (BNCT) comes not only from heavy charged particles produced from the ${ }^{10} B(n, \alpha)^{7}$ Li nuclear reaction, but also from neutron-induced reactions with other biological elements in living tissue, as well as from gamma rays leaked from the reactor core. At Dalat Research Reactor, Vietnam, the neutron and gamma dose rate distribution inside a water phantom were measured by using activation method and Thermoluminescent Dosimeter (TLD) detector, respectively. The results showed that effective thermal neutron dose rate along the center line of the water phantom had a maximum value of $479 \mathrm{mSv} \mathrm{h}^{-1}$ at $1 \mathrm{~cm}$ in phantom and then decreases rapidly to $4.87 \mathrm{mSv} \mathrm{h}^{-1}$ at $10 \mathrm{~cm}$. The gamma dose rate along the center line of the water phantom also reach its maximum of $4.31 \mathrm{mSv} \mathrm{h}^{-1}$ at $1 \mathrm{~cm}$ depth and decreases to 1.16 $m S v h^{-1}$ at $10 \mathrm{~cm}$ position. The maximum biological tumor dose rate was $1.74 \mathrm{~Gy}$-eq $\mathrm{h}^{-1}$, not high enough to satisfy the treatment requirement of brain tumors. However, the results of this work are important in supporting of BNCT study in the upcoming stages at Dalat Research Reactor.

Keywords: BNCT; dose rate; TLD detector; thermal neutron flux; water phantom

\section{ABSTRAK}

Kadar dos pendedahan kepada tumor dan sel sekitarnya semasa pancaran sinaran neutron dalam Terapi Boron Neutron Tertawan (BNCT) datang bukan sahaja daripada zarah berat bercas yang dihasilkan daripada tindak balas nuklear ${ }^{10} \mathrm{~B}(\mathrm{n}, \alpha)^{7} \mathrm{Li}$, tetapi juga daripada tindak balas neutron-teraruh daripada unsur biologi lain dalam tisu hidup, selain daripada sinar gama yang bocor daripada teras reaktor. Di Reaktor Penyelidikan Dalat, Vietnam, kadar pengagihan dos neutron dan gama dalam fantom air diukur masing-masing menggunakan kaedah pengaktifan dan pengesan Thermoluminescent Dosimeter (TLD). Keputusan menunjukkan bahawa kadar dos haba neutron yang berkesan sepanjang garis tengah fantom air mempunyai nilai maksimum $479 \mathrm{mSv} h^{-1}$ pada $1 \mathrm{~cm}$ dalam phantom dan kemudian menurun dengan pantas kepada $4.87 \mathrm{mSv} h^{-1}$ pada $10 \mathrm{~cm}$. Kadar dos gama sepanjang garis tengah fantom air juga mencapai tahap maksimum $4.31 \mathrm{mSv} \mathrm{h}^{-1}$ pada kedalaman $1 \mathrm{~cm}$ dan menurun ke $1.16 \mathrm{mSv} \mathrm{h}^{-1}$ pada kedudukan $10 \mathrm{~cm}$. Kadar dos maksimum tumor biologi adalah 1.74 Gy-eq $h^{-1}$ namun tidak cukup tinggi untuk memenuhi keperluan rawatan tumor otak. Walau bagaimanapun, keputusan kajian ini adalah penting dalam menyokong pengajian BNCT pada peringkat akan datang di Reaktor Penyelidikan Dalat.

Kata kunci: BNCT; fantom air; fluks haba neutron; kadar dos; pengesan TLD

\section{INTRODUCTION}

Boron Neutron Capture Therapy (BNCT) is a very effective cancer treatment technique for several types of brain tumor (Dao-wen et al. 2012; Marashi 2000; Perks et al. 1988). This technique is based on the bombardment of Boron with low energy thermal neutron that yields alpha particles $\left({ }^{4} \mathrm{He}\right)$ and recoiling lithium nuclei $\left({ }^{7} \mathrm{Li}\right)$. These charged particles have high kinetic energy to kill tumor cells (Bortolussi \& Altieri 2007; Dao-wen et al. 2012; Perks et al. 1988), their short ranges in matters reduce the damage to healthy tissues surrounding the tumor. However, healthy cells are damaged during neutron beam irradiation. This side effect comes not only from products generated from other neutron-induced reactions with elements in living tissue, but also from gamma rays leaking from the reactor core (Takada et al. 2014). In general, the dose rate in both tumor and healthy tissue are mainly subjected to the level of the thermal neutron flux. The gamma dose rate is mainly produced from the ${ }^{1} \mathrm{H}(\mathrm{n}, \gamma)^{2} \mathrm{H}$ reaction (Sauerwein et al. 2012). Determination of neutron and gamma dose rate is an important issue in BNCT to ensure the efficacy of the treatment and safety for both patients and operators. 
In general, the magnitude of neutrons flux for a successful BNCT treatment should be in the order of $10^{9}$ $10^{12} \mathrm{n} \mathrm{cm}^{-2} \mathrm{~s}^{-1}$ (Akan et al. 2015). To achieve this neutron flux, accelerators or research reactors are employed. In some cases, research reactors were modified to provide such a high neutron flux. Particularly, TRIGA MARK II reactor was utilized due to many advantages presented elsewhere (Whittemore 1992), for instance, TRIGA MARK II reactor of the Istanbul Technical University (IAEA 2016), J. Stefan TRIGA MARK-II reactor at J. Stefan Institute in Slovenia (Maučec 2001), TRIGA reactor of the University of Mainz, Germany (Nagels et al. 2009), TRIGA Mushashi reactor in Japan (Matsumoto 1996) and TRIGA reactor of the University of Pavia-Italy (Bortolussi et al. 2018) have been used for BNCT study with some modifications to the beam port or thermal column.

At present, Vietnam has only one research reactor - Dalat Research Reactor (DRR) -dedicated to training, radioisotope production, neutron activation analysis and basic research. Up to now, there is no research on BNCT in Vietnam. Hence, a pilot project for BNCT study is being carried out to examine the capability of developing such system at the DRR. As a major target in the first stage of the project, the purpose of this study was to determine the neutron flux and gamma dose rates in a water phantom when irradiated at channel No. 2 of the DRR. The results from this study would serve as a basis for future designs and development of the BNCT system at the DRR in the future which has given many attentions in Vietnam as a promising treatment for patients with brain tumor. In the near future, a new multi-purposes open - pool 15 MW research reactor will be constructed in Vietnam with a thermal neutron flux of $3.0 \times 10^{14} \mathrm{n} \mathrm{cm}^{-2} \mathrm{~s}^{-1}$. As designed, there will be 6 horizontal neutron channels for fundamental researches including BNCT and PGNAA (Nguyen et al. 2012).

\section{MATERIALS AND METHODS}

\section{BACKGROUND OF THE DDR CHANNEL NO.2}

The DRR is a $500 \mathrm{~kW}$ pool-type research reactor using light water as both moderator and coolant. Since 2011, various neutron filters have been designed, manufactured and successfully installed at the horizontal channel No. 2 of the DRR to produce neutrons with specific energy of interest for the purposes of prompt gamma neutron activation analysis, neutron radiography and neutron dose standardization. Neutron spectrum from channel No. 2 with silicon-bismuth crystal filter is shown in Figure 1.

\section{EXPERIMENT SETUP USING WATER PHANTOM}

In view of thermal neutron utilization, a filter consisted of $4 \mathrm{~cm} \mathrm{Bi}$ and $80 \mathrm{~cm} \mathrm{Si} \mathrm{was} \mathrm{employed} \mathrm{for} \mathrm{this} \mathrm{experiment.}$ Parameters of the thermal neutron beam line right at the outer of the horizontal channel No.2 with this type of filter is presented in Table 1 .

Due to a similar proton density as that of the normal brain tissue, the water phantom has often been used to study the thermal neutron flux distribution in BNCT (Yamamoto et al. 2002). In this work, a water phantom with a rectangular shape of $16 \mathrm{~cm} \times 16 \mathrm{~cm} \times 25 \mathrm{~cm}$ was made out of $2 \mathrm{~mm}$ glass plates and filled with purified water. The top cover of the phantom was designed with an array of holds for manual insertion and withdrawal of the foils or the Thermoluminescent Dosimeter (TLD) detectors. The phantom is illustrated in Figure 2.

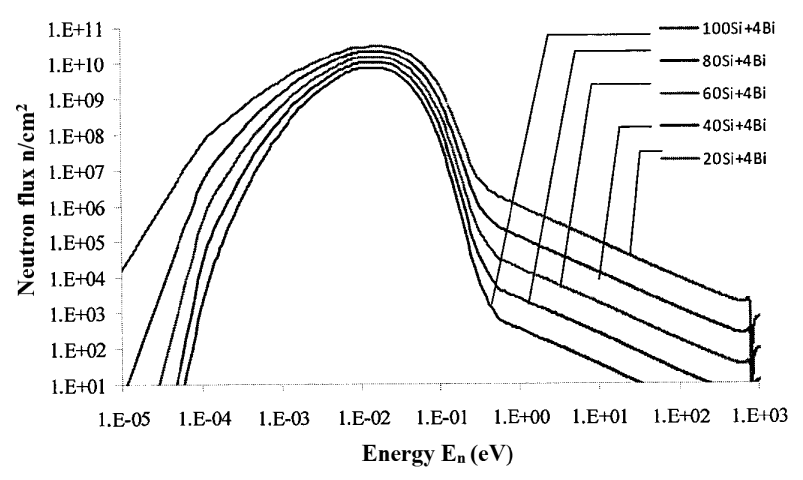

FIGURE. 1 Neutron spectrum from channel No.2 with Si-Bi crystal filter

TABLE 1. Parameters of the thermal neutron beam line at outer of the horizontal channel No. 2 of the DRR (Tan \& Son 2016)

\begin{tabular}{cccc}
\hline $\begin{array}{c}\text { Thermal neutron flux } \phi_{\text {th }} \\
\left(\mathrm{n} \mathrm{cm}^{-2} \mathrm{~s}^{-1}\right)\end{array}$ & $\begin{array}{c}\text { Cadmium ratio } \\
\mathrm{R}_{\mathrm{Cd}}(\mathrm{Au})\end{array}$ & Filter materials & $\begin{array}{c}\text { Beam diameter } \\
(\mathrm{cm})\end{array}$ \\
\hline $1.6 \times 10^{6}$ & 420 & $4 \mathrm{~cm} \mathrm{Bi}+80 \mathrm{~cm} \mathrm{Si}$ & 3 \\
\hline
\end{tabular}




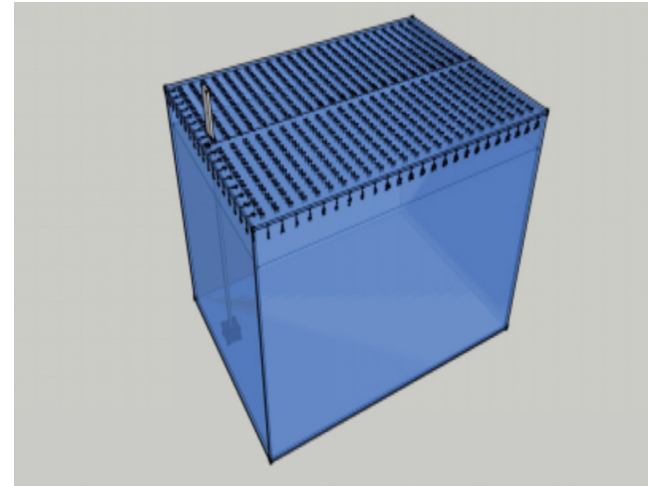

FIGURE 2. The rectangular water phantom

In order to measure thermal neutron flux in the phantom, activation method was used in which foils of natural Vanadium element $\left({ }^{51} \mathrm{~V}\right)$ was used as activation foils. The ${ }^{51} \mathrm{~V}$ foil has a diameter of $1.27 \mathrm{~cm}$ and a purity of $99.98 \%$.

\section{IRRADIATION OF THE PHANTOM AND ACTIVITY MEASUREMENT OF THE IRRADIATED FOILS}

The experimental setup at the neutron beam channel No. 2 of the DRR are presented in Figure 3.

The water phantom was irradiated with the thermal neutron beam at the horizontal channel No. 2 of the DRR after the reactor has operated at $500 \mathrm{~kW}$ of power for $24 \mathrm{~h}$. Each foil was placed in the phantom at the position of interest. Activity of the foil was analyzed with the parameters presented in Table 2.

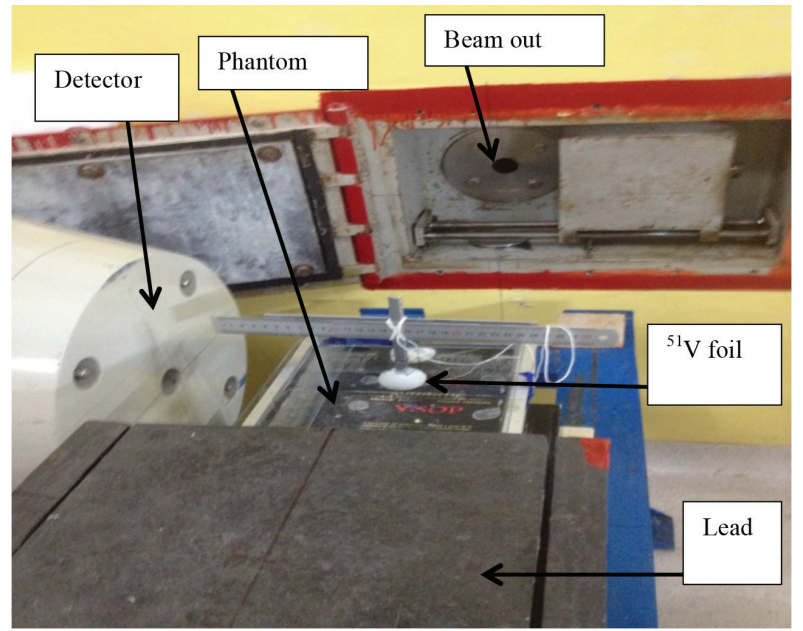

FIGURE 3. Experimental set up at the neutron beam channel No. 2 of DRR at the DRR
A modern gamma-ray spectroscopy (ORTEC DSPEC) in compact with a high efficiency and high purity Germanium (HPGe) detector was used to measure the specific radioactivity of the irradiated foils. The detector was calibrated by using a set of standard radioisotope sources: ${ }^{152} \mathrm{Eu},{ }^{60} \mathrm{Co},{ }^{57} \mathrm{Co},{ }^{137} \mathrm{Cs},{ }^{241} \mathrm{Am},{ }^{113} \mathrm{Sn}$ and ${ }^{88} \mathrm{Y}$. The absolute detection efficiency function for $5 \mathrm{~cm}$ distance from the end-cap of the detector was also simulated by Monte Carlo Geant4 toolkit. The results of simulation and measurement of the efficiency curve are illustrated in Figure 4.

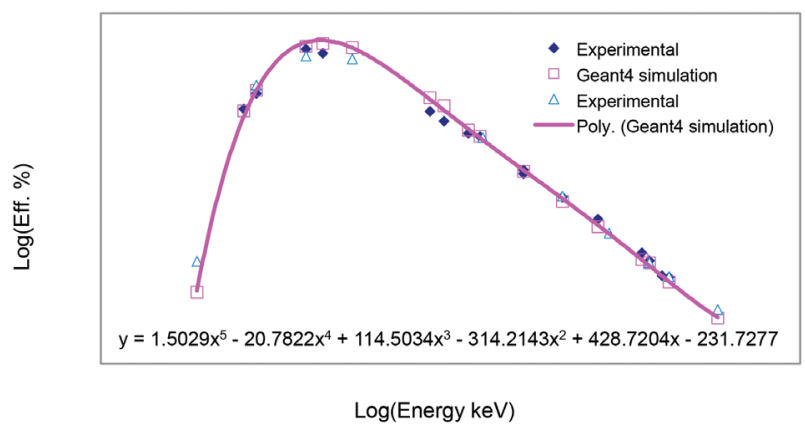

FIGURE 5. The absolute detection efficiency curve of the HPGe detector for standard foils at $5 \mathrm{~cm}$ from the detector end-cap

The thermal neutron flux is determined from the activity of the Vanadium foil as follows (Akhlaghi et al. 2013; Tan \& Son 2016; Yamamoto et al. 2002),

$$
\phi=\frac{C f_{c} \lambda}{\varepsilon_{\gamma} I_{\gamma} N \sigma_{0}\left(1-e^{-\lambda t_{1}}\right) e^{-\lambda t_{2}}\left(1-e^{-\lambda t_{3}}\right)}
$$

where $\mathrm{C}$ denotes the net counts of the corresponding gamma peak; $f_{c}$ is the correction factor for the effects of neutron multiple scattering and self-shielding in the irradiated foils; $\lambda$ is the decay constant of the product nucleus; $\varepsilon_{\gamma}$ is the detection efficiency of the detector; $\mathrm{I}_{\gamma}$ is the intensity of gamma peak of interest; $\mathrm{N}$ is the number of nuclei in the sample; $\sigma_{0}$ is the average thermal neutron capture cross section; $t_{1}, t_{2}$ and $t_{3}$ are irradiating, cooling and measuring times, respectively.

The decay characteristics of ${ }^{51} \mathrm{~V}$ nucleus after capturing a thermal neutron is presented in Table 3 .

The TLD detectors have also been used to measure gamma dose. Every TLD detector was placed at a specific position along the center line of the phantom and was irradiated for 1 to $2 \mathrm{~h}$. After that, the TLD detector was

TABLE 2. Irradiation and measurements details for ${ }^{51} \mathrm{~V}$ standard foil by INAA (IAEA 2001)

\begin{tabular}{cccc}
\hline $\begin{array}{c}\text { Nuclide used, } \\
\text { mass }(\mathrm{g})\end{array}$ & $\begin{array}{c}\text { Irradiation time } \\
(\mathrm{s})\end{array}$ & $\begin{array}{c}\text { Cooling time } \\
(\mathrm{s})\end{array}$ & $\begin{array}{c}\text { Measurement time } \\
(\mathrm{s})\end{array}$ \\
\hline${ }^{51} \mathrm{~V}, 0.0925$ & $60-960$ & $176-1800$ & $201-1250$ \\
\hline
\end{tabular}


TABLE 3. Decay properties of the activation product nuclei (Glascock 1998)

\begin{tabular}{cccc}
\hline $\begin{array}{c}\text { Activation } \\
\text { product }\end{array}$ & $\begin{array}{c}\text { Half-life } \\
(\mathrm{m})\end{array}$ & $\begin{array}{c}\gamma \text {-ray } \\
(\mathrm{keV})\end{array}$ & $\begin{array}{c}\text { Intensity } \\
(\%)\end{array}$ \\
\hline${ }^{52} \mathrm{~V}$ & 3.75 & 1434.08 & 100 \\
\hline
\end{tabular}

replaced with a new one and the irradiation process was repeated for a similar period of time.

\section{RESULTS AND DISCUSSION}

Thermal neutron and gamma flux distribution in the water phantom has been measured along the center line. Measurements have been carried out at the reactor power of $500 \mathrm{~kW}$. A conversion factor with a value of $9.70 \times 10^{10}$ $\mathrm{n} \mathrm{cm}^{-2} \mathrm{~s}^{-1} \mathrm{~Sv}^{-1}$ (Kwon et al. 1980) had been used to convert thermal neutron flux to the whole body effective neutron dose rate. The measured two-dimensional thermal neutron flux and whole body effective dose rate distribution of neutron are shown in Figure 5.

The total gamma dose rate at depth positions along the inner center-line of the phantom are measured by using the TLD dosimeters. The obtained results are shown in Figure 6.

The gamma dose rate drops significantly with increasing depth in the phantom, decreases from 5.5 to $0.57 \mathrm{mSv} / \mathrm{h}$ over a range of $14 \mathrm{~cm}$. Then, the gamma dose rate levels off.

However, in BNCT, the radiation dose delivered to the target organ having the tumor is much significant than other organs. Thus, the radiation dose absorbed by the brain was estimated separately. In terms of BNCT, the biological tumor dose rate in unit of Gy-eq $\mathrm{h}^{-1}$ was defined as (Jarahi et al. 2016):

$$
\mathrm{D}=\mathrm{w}_{\mathrm{n}} \times \mathrm{D}_{\text {therma } 1}+\mathrm{w}_{\mathrm{g}} \times \mathrm{D}_{\text {gamma }}+\mathrm{CBE} \times \mathrm{D}_{\text {Boron }}
$$

where $\mathrm{D}$ is the total dose, $\mathrm{D}_{\text {thermal }}, \mathrm{D}_{\text {gamma }}, \mathrm{D}_{\text {boron }}$ are the absorbed dose from thermal neutron, gamma and charged particles from $\left.{ }^{10} \mathrm{~B}(\mathrm{n}, \alpha)\right)^{7} \mathrm{Li}$ reactions while the $\mathrm{w}_{\mathrm{n}}$ and $\mathrm{w}_{\mathrm{g}}$ is the radiation weighting factor for thermal neutron and gamma, with their values being 3.2 and 1, respectively. The Compound Biological Effectiveness (CBE) is equal to 3.8 for tumor and 1.3 for normal tissue.

The absorbed dose from thermal neutrons and ${ }^{10} \mathrm{~B}(\mathrm{n}, \alpha)^{7} \mathrm{Li}$ reactions in (2) is calculated. The absorbed dose component due to thermal neutron $\left(\mathrm{D}_{\text {thermal }}\right)$ is calculated based on Kerma factor for different tissues $\left(\mathrm{k}_{\mathrm{r}}\right)$ as in (3) (Singh et al. 2015),

$$
k_{T}(E)=\sum_{i} w_{i} k_{f}(E)_{i}
$$
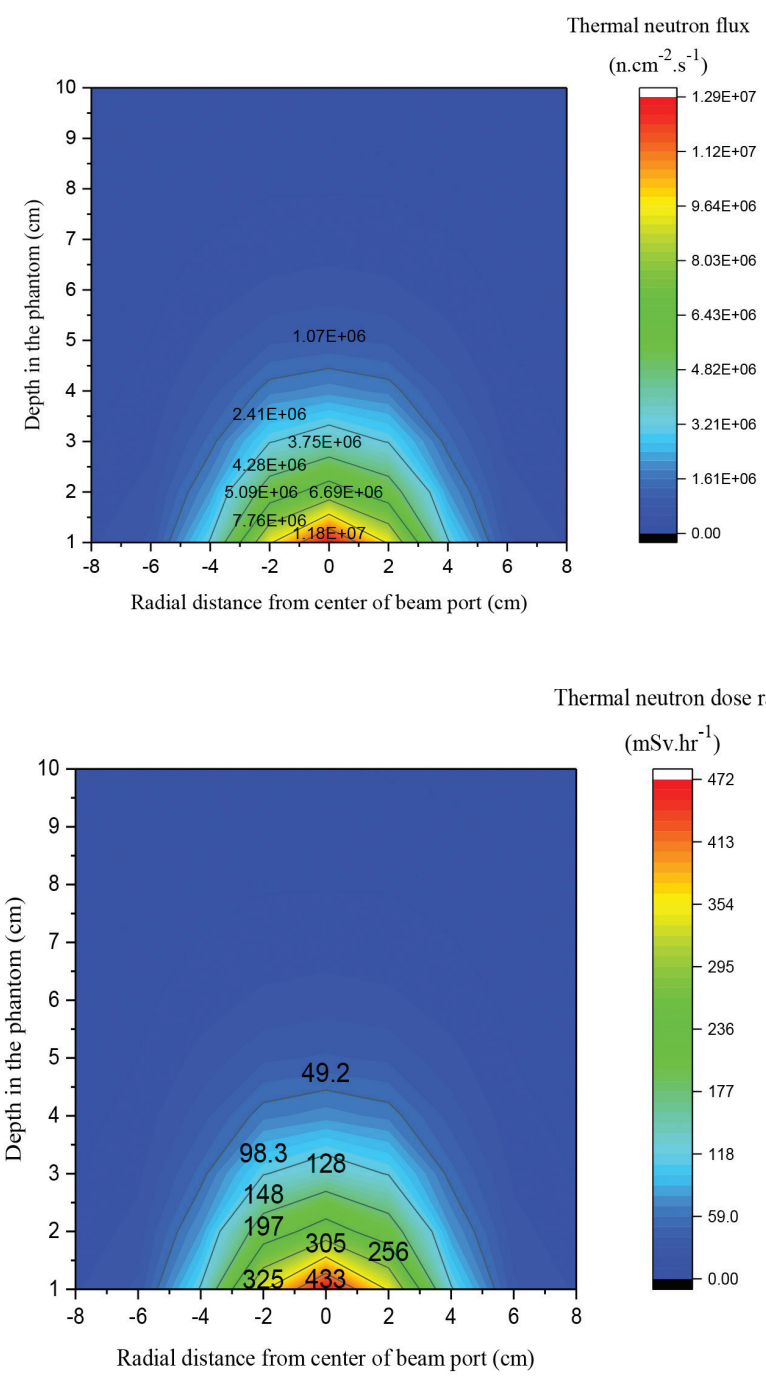

FIGURE 5. Two-dimensional thermal neutron (a) flux and

(b) dose rate distribution in the phantom

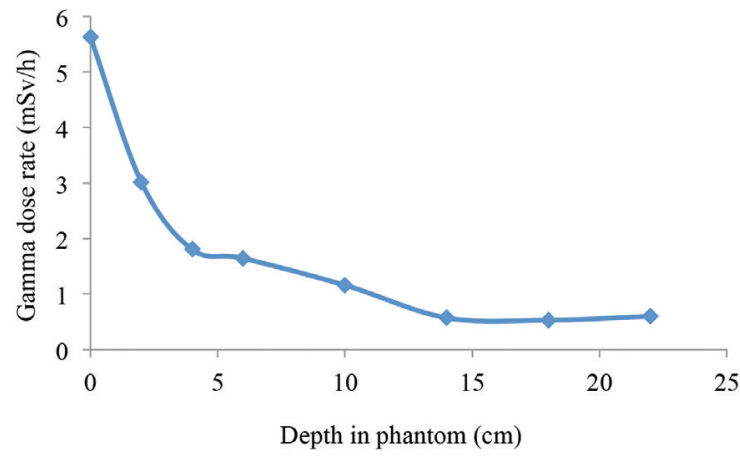

FIGURE 6. Gamma dose rate at depth positions along the center-line of the phantom

where $\mathrm{w}_{\mathrm{i}}$ is the percent composition by weight of ith element in tissue; and $k_{f}(E)_{i}$ is the kerma factor of ith element in tissue. The element components and corresponding $\mathrm{w}_{\mathrm{i}}$ values for brain tissue are suggested in ICRU 46 (White et al. 1992) as shown in Table 4. 
TABLE 4. Material composition of an adult whole brain

\begin{tabular}{cccccccccc}
\hline Composition & $\mathrm{H}$ & $\mathrm{C}$ & $\mathrm{N}$ & $\mathrm{O}$ & $\mathrm{Na}$ & $\mathrm{P}$ & $\mathrm{S}$ & $\mathrm{Cl}$ & $\mathrm{K}$ \\
\hline $\begin{array}{c}\text { Weight } \\
\text { percentage }\end{array}$ & 10.7 & 14.5 & 2.2 & 71.2 & 0.2 & 0.4 & 0.2 & 0.3 & 0.3 \\
\hline
\end{tabular}

If the neutron beam is comprised of thermal neutrons only, the kerma factor for brain tissues is calculated using (3) with element compositions specified in Table 4:

$$
\begin{aligned}
k_{\text {brain }}(0.025 \mathrm{eV})= & w_{H} k_{H}+w_{C} k_{C}+w_{N} k_{N}+w_{O} k_{O} \\
& +w_{N a} k_{N a}+w_{P} k_{P}+w_{S} k_{S}+w_{C l} k_{C l} \\
& +w_{K} k_{K}+w_{C a} k_{C a} \\
= & 1.830 \times 10^{-13}\left(\mathrm{~Gy} . \mathrm{cm}^{2}\right)
\end{aligned}
$$

The biologically weighted dose of thermal neutron is then calculated using (5).

$$
\mathrm{D}_{\text {thermal }}=\mathrm{k}_{\text {brain }}(0.025 \mathrm{eV}) \times \mathrm{f}_{\text {th }} \text {. }
$$

where $\mathrm{f}_{\text {th }}$ is the thermal neutron flux.

The dose rate from ${ }^{10} \mathrm{~B}(\mathrm{n}, \alpha)^{7} \mathrm{Li}$ reactions $\left(\mathrm{D}_{\text {Boron }}\right)$ is calculated using (6) (Horiguchi et al. 2014),

$$
\mathrm{D}_{\text {Boron }}=\mathrm{k}_{\mathrm{B}} \times \mathrm{f}_{\text {th }} \times \mathrm{C}_{\mathrm{B}}
$$

where $k_{B}$ is the kerma factor for the boron dose which was evaluated to be $7.51 \times 10^{-14} \mathrm{~Gy} \mathrm{~cm}^{-2} \mathrm{ppm}^{-1}$. $\mathrm{C}_{\mathrm{B}}$ is the concentration of ${ }^{10} \mathrm{~B}$ in target tissues, having unit of part per million. Boron dose presents not only in the tumor but in the surrounding normal tissues since the boron transmits throughout the body after the boron drug was injected to the patient's blood vein. Because the phantom in this experiment contained only pure water so the boron dose in this calculation is an evaluation for future work. Normally, the boron concentration ratio in tumor and normal tissue should be around 3.5 (Goorley et al. 2002; Moghaddasi \& Bezak 2017). Thus, in this study, the ${ }^{10} \mathrm{~B}$ concentration is set at $12 \mathrm{ppm}$ in the normal tissue and $42 \mathrm{ppm}$ in the tumor. The calculated values of biologically weighted doses using (2) and whole body effective dose rate on the center line of the phantom were reported in Table 5.

Figure 7 shows the biologically weighted dose rates distribution as functions of depth in the phantom, through the center axis of the beam exit. As shown in Figure 8, the thermal neutron flux had a maximum value at $1 \mathrm{~cm}$ depth in the phantom, consequently the thermal neutron dose rate also reaches its maximum at $1 \mathrm{~cm}$ depth, and then decreases rapidly. The boron dose distribution also had similar behavior, with the dose in the tumor accounting for the majority of the dose received during neutron irradiation. In contrast, thermal neutron, gamma and boron dose in normal tissues contribute an insignificant amount to the total dose within the target organ. The maximum achieved value of biological tumor dose rate was $8.04 \times 10^{-1} \mathrm{~Gy}$-eq $\mathrm{h}^{-1}$.

The dose rates in the phantom of this research has a similar shape with those in the work of Bavarnegin et al. (2016). However, the total biological tumor dose rates in this research is much lower, namely $8.04 \times 10^{-1} \mathrm{~Gy}_{-} \mathrm{eq} \mathrm{h}^{-1}$ compared to $72 \mathrm{~Gy}$-eq $\mathrm{h}^{-1}$. In fact, the thermal neutron flux at the channel No. 2 of the DRR is nearly 10 times lower and the assumed boron concentration is also lower compared to values reported by Bavarnegin et al. (2016).

TABLE 5. The biological weighted dose rate of thermal neutron, the boron dose rates and whole body total effective dose rate along the center line of the phantom

\begin{tabular}{ccccccc}
\hline Position & $\begin{array}{c}\text { Biologically } \\
\text { weighted dose rate } \\
\text { of thermal neutron }\end{array}$ & $\begin{array}{c}\text { Biologically } \\
\text { weighted dose } \\
\text { rate of gamma }\end{array}$ & $\begin{array}{c}\text { Biologically weighted } \\
\text { boron dose ratefor } \\
\text { normal tissues }\end{array}$ & $\begin{array}{c}\text { Biologically } \\
\text { weighted boron } \\
\text { dose rate for } \\
\text { tumor }\end{array}$ & $\begin{array}{c}\text { Total } \\
\text { biologically } \\
\text { weighted dose } \\
\text { rate }\end{array}$ & $\begin{array}{c}\text { Whole body } \\
\text { effective dose } \\
\text { rate }\end{array}$ \\
\hline$(\mathrm{cm})$ & $(\mathrm{Gy}-\mathrm{eq} / \mathrm{h})$ & $(\mathrm{Gy}$-eq/h) & $(\mathrm{Gy}-\mathrm{eq} / \mathrm{h})$ & $(\mathrm{Gy}-\mathrm{eq} / \mathrm{h})$ & $(\mathrm{Gy}-\mathrm{eq} / \mathrm{h})$ & $(\mathrm{mSv} / \mathrm{h})$ \\
\hline 1 & $1.94 \mathrm{E}-01$ & $4.37 \mathrm{E}-03$ & $5.40 \mathrm{E}-02$ & $5.52 \mathrm{E}-01$ & $8.04 \mathrm{E}-01$ & $4.79 \mathrm{E}+02$ \\
2 & $1.09 \mathrm{E}-01$ & $3.01 \mathrm{E}-03$ & $3.02 \mathrm{E}-02$ & $3.09 \mathrm{E}-01$ & $4.51 \mathrm{E}-01$ & $2.68 \mathrm{E}+02$ \\
3 & $5.75 \mathrm{E}-02$ & $2.73 \mathrm{E}-03$ & $1.60 \mathrm{E}-02$ & $1.64 \mathrm{E}-01$ & $2.40 \mathrm{E}-01$ & $1.43 \mathrm{E}+02$ \\
4 & $3.05 \mathrm{E}-02$ & $1.80 \mathrm{E}-03$ & $8.48 \mathrm{E}-03$ & $8.67 \mathrm{E}-02$ & $1.27 \mathrm{E}-01$ & $7.64 \mathrm{E}+01$ \\
5 & $1.68 \mathrm{E}-02$ & $1.65 \mathrm{E}-03$ & $4.68 \mathrm{E}-03$ & $4.79 \mathrm{E}-02$ & $7.10 \mathrm{E}-02$ & $4.27 \mathrm{E}+01$ \\
6 & $1.02 \mathrm{E}-02$ & $1.64 \mathrm{E}-03$ & $2.82 \mathrm{E}-03$ & $2.89 \mathrm{E}-02$ & $4.36 \mathrm{E}-02$ & $2.65 \mathrm{E}+01$ \\
7 & $6.00 \mathrm{E}-03$ & $1.13 \mathrm{E}-03$ & $1.67 \mathrm{E}-03$ & $1.70 \mathrm{E}-02$ & $2.58 \mathrm{E}-02$ & $1.57 \mathrm{E}+01$ \\
8 & $3.75 \mathrm{E}-03$ & $1.08 \mathrm{E}-03$ & $1.04 \mathrm{E}-03$ & $1.07 \mathrm{E}-02$ & $1.66 \mathrm{E}-02$ & $1.01 \mathrm{E}+01$ \\
10 & $1.52 \mathrm{E}-03$ & $1.16 \mathrm{E}-03$ & $4.21 \mathrm{E}-04$ & $4.31 \mathrm{E}-03$ & $7.41 \mathrm{E}-03$ & $4.87 \mathrm{E}+00$ \\
\hline
\end{tabular}




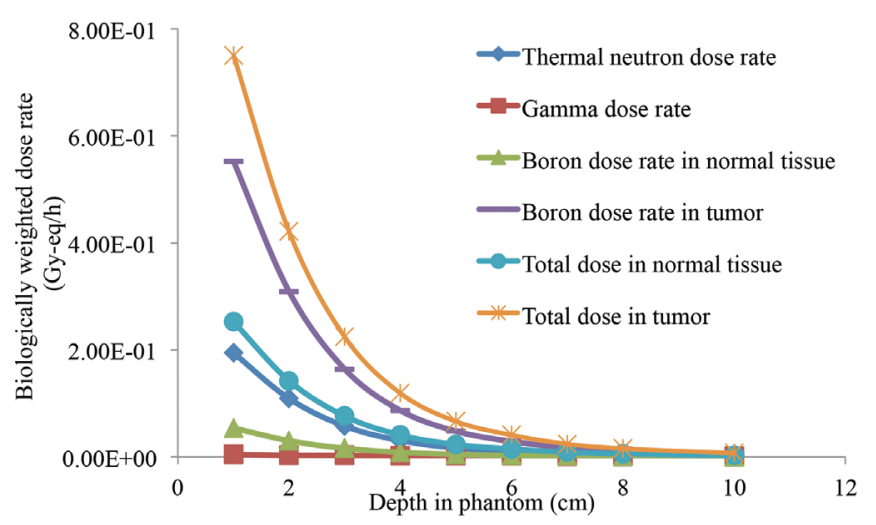

FIGURE 7. Biologically weighted dose rate distribution along the center line of the water phantom

\section{CONCLUSION}

The thermal neutron flux distribution in the water phantom irradiated at Channel No. 2 of the DRR was determined by using activation method with ${ }^{51} \mathrm{~V}$ foils as activation foils. The results showed that thermal neutron dose rate along center line of the water phantom had a maximum value $479 \mathrm{mSv} \mathrm{h}^{-1}$ at $1 \mathrm{~cm}$ in phantom and then decreases rapidly to $4.87 \mathrm{mSv} \mathrm{h}^{-1}$ at $10 \mathrm{~cm}$. The gamma dose is insignificant due to its low magnitude. The current configuration of channel No. 2 at the DRR is not able to be used for BNCT due to the low biological dose rate, with its maximum value being $8.04 \times 10-1$ Gy-eq $\mathrm{h}^{-1}$ at $1 \mathrm{~cm}$ depth in the phantom. However, the results of this work are still important for future BNCT study at DRR, especially when a new reactor with much higher power is to be built.

\section{ACKNOWLEDGEMENTS}

This work is supported by the Ministry of Education and Training of Vietnam under the project code: B2016-TDL-01.

\section{REFERENCES}

Akan, Z., Türkmen, M., Çakır, T., Reyhancan, I.A., Çolak, Ü., Okka, M. \& Kizıltaş, S. 2015. Modification of the radial beam port of ITU TRIGA Mark II research reactor for BNCT applications. Appl. Radiat. Isot. 99: 110-116.

Akhlaghi, P., Rafat-Motavalli, L. \& Miri-Hakimabad, S.H. 2013. The measurements of thermal neutron flux distribution in a paraffin phantom. Pramana - J. Phys. 80(5): 873-885.

Bavarnegin, E., Sadremomtaz, A., Khalafi, H. \& Kasesaz, Y. 2016. Measurement of in-phantom neutron flux and gamma dose in Tehran research reactor boron neutron capture therapy beam line. J. Cancer Res. Ther. 12(2): 826-829.

Bortolussi, S. \& Altieri, S. 2007. Thermal neutron irradiation field design for boron neutron capture therapy of human explanted liver. Med. Phys. 34(12): 4700-4705.

Bortolussi, S., Protti, N., Ferrari, M., Postuma, I., Fatemi, S., Prata, M., Ballarini, F., Carante, M.P., Farias, R., González, S.J., Marrale, M., Gallo, S., Bartolotta, A., Iacoviello, G., Nigg, D. \& Altieri, S. 2018. Neutron flux and gamma dose measurement in the BNCT irradiation facility at the TRIGA reactor of the University of Pavia. Nucl. Instrum. Methods Phys. Res. B 414: 113-120.

Dao-wen, C., Jing-bin, L., Dong, Y., Hui-dong, W. \& Ke-yan, M. 2012. Improvement of the moderator's thermalization efficiency for $14 \mathrm{MeV}$ neutrons in boron neutron capture therapy. J. Radioanal. Nucl. Chem. 292(3): 1085-1088.

Glascock, M.D. 1998. Activation analysis. In Instrumental Multi-Element Chemical Analysis, edited by Alfassi, Z.B. Dordrecht: Springer.

Goorley, J.T., Kiger, W.S. \& Zamenhof, R.G. 2002. Reference dosimetry calculations for neutron capture therapy with comparison of analytical and voxel models. Med. Phys. 29(2): 145-156.

Horiguchi, H., Sato, T., Kumada, H., Yamamoto, T. \& Sakae, T. 2014. Estimation of relative biological effectiveness for boron neutron capture therapy using the PHITS code coupled with a microdosimetric kinetic model. J. Radiat.Res. 56(2): 382-390.

IAEA. 2016. History, Development and Future of TRIGA Research Reactor. IAEA, Vienna, Technical Report Series No. $482,131$.

IAEA. 2001. Use of Research Reactors for Neutron Activation Analysis. IAEA, Vienna, IAEA-TECDOC-1215.

Jarahi, H., Kasesaz, Y. \& Saleh-Koutahi, S.M. 2016. Evaluation of the effective dose during BNCT at TRR thermal column epithermal facility. Appl. Radiat. Isot. 110: 134-137.

Kwon, S.G., Kim, K.E., Ha, C.W., Moon, P.S. \& Yook, C.C. 1980. Calculation of neutron and gamma-ray flux-to-dose-rate conversion factors. J. Nucl. Eng. Technol. 12(3): 171-179.

Marashi, M.K. 2000. Analysis of absorbed dose distribution in head phantom in boron neutron capture therapy. Nucl. Instrum. Methods Phys. Res. A 440(2): 446-452.

Matsumoto, T. 1996. Design of neutron beams for boron neutron capture therapy for TRIGA Reactor.Prog.Nucl. Sci. Technol. 33(2): 171-178.

Maučec, M. 2001. Feasibility of the Utilization of BNCT in Thermalizing Column of TRIGA Reactor. In Frontiers in Neutron Capture Therapy. 1st ed., edited by Hawthorne, M.F., Shelly, K. \& Wiersema, R.J. Boston, MA: Springer.

Moghaddasi,L. \& Bezak, E. 2017. Development of an integrated Monte Carlo model for glioblastoma multiforme treated with boron neutron capture therapy. Sci. Rep. 7(1): 7069.

Nagels, S., Hampel, G., Kratz, J.V., Aguilar, A.L., Minouchehr, S., Otto, G., Schmidberger, H., Schütz, C., Vogtländer, L. \& 
Wortmann, B. 2009. Determination of the irradiation field at the research reactor TRIGA Mainz for BNCT. Appl. Radiat. Isot. 67(7-8): S242-S246.

Nguyen, K.C., Huynh, T.N., Le, V.V. \& Luong, B.V. 2012. The role of a research reactor in the National Nuclear Energy Programme in Vietnam: Present and future. In Research Reactors: Safe Management and Effective Utilization. Proceedings of an International Conference, IAEA, Morocco.

Perks, C.A., Mill, A.J., Constantine, G., Harrison, K.G. \& Gibson, J.A.B. 1988. A review of boron neutron capture therapy (BNCT) and the design and dosimetry of a high-intensity, $24 \mathrm{keV}$, neutron beam for BNCT research. Br. J. Radiol. 61(732): 1115-1126.

Sauerwein, W.A.G., Wittig, A., Moss, R. \& Nakagawa, Y. 2012. Neutron Capture Therapy. Springer, Berlin, Heidelberg.

Singh, V.P., Badiger, N.M. \& Vega-Carrillo, H.R. 2015. Neutron kerma coefficients of compounds for shielding and dosimetry. Ann. Nucl. Ener. 75: 189-192.

Takada, K., Isobe, T., Kumada, H., Yamamoto, T., Shida, K., Kobayashi, D., Mori, Y., Sakurai, H. \& Sakae, T. 2014. Evaluation of the radiation dose for whole body in boron neutron capture therapy. Prog. Nucl.Sci.Technol. 4: 820-823.

Tan, V.H. \& Son, P.N. 2016. Thermal neutron radiative capture cross-section of ${ }^{186} \mathrm{~W}(\mathrm{n}, \gamma)^{187} \mathrm{~W}$ reaction. J. Phys. Conf. Ser. 726: 012004.

White, D.R., Griffith, R.V. \& Wilson, I.J. 1992. Journal of the International Commission on Radiation Units and Measurements 24(1): 1-4.

Whittemore, W.L. 1992. A compact triga reactor for Boron Neutron Capture Therapy. In Progress in Neutron Capture Therapy for Cancer. 1st ed., edited by Allen, B.J., Moore, D.E. \& Harrington, B.V. Boston, MA: Springer.
Yamamoto, T., Matsumura, A., Yamamoto, K., Kumada, H., Shibata, Y. \& Nose, T. 2002. In-phantom two-dimensional thermal neutron distribution for intraoperative boron neutron capture therapy of brain tumours. Phys. Med. Biol. 47(14): 2387-2396.

Trinh Thi Tu Anh* \& Pham Dang Quyet

Dalat University

01 Phu Dong Thien Vuong, Dalat

Vietnam

Mai Nguyen Trong Nhan

Ulsan National Institute of Science and Technology

Ulsan 44919

Republic of Korea

Pham Ngoc Son

Nuclear Research Institute

01 Phu Dong Thien Vuong, Dalat

Vietnam

*Corresponding author; email: anhttt@dlu.edu.vn

Received: 7 June 2018

Accepted: 7 September 2018 